\title{
Retail Mobility Environments: A methodological framework for integrating retail activity and non-motorised accessibility in Zaragoza, Spain
}

\author{
Aldo Arranz-López , Julio A Soria-Lara , Carlos López-Escolano , Ángel Pueyo Campos
}

While adequate integration of land use and transport is seen as crucial for achieving sustainable outcomes, the reciprocal interconnection between retail activity and non-motorised accessibility is yet to be adequately exam-ined. To address this gap, this paper proposes the concept of Retail Mobility Environment (RME) and develops a methodological process for identifying and mapping RMEs, using the city of Zaragoza, Spain, as a case study. The concept of RME is developed through three methodological phases: (i) definition of non-motorised Accessibility Zones (AZs), using three indicators (walking accessibility, bicycling accessibility, betweenness); (ii) definition of Retail Zones (RZs), also using three indicators (retail density, retail diversity, retail contiguity); and (iii) definition of RMEs, where both retail activity and non-motorised indicators were weighted and combined using multi-criteria analysis. In total, four RMEs were identified and mapped: short-distance environments, motorised envi-ronments, non-motorised environments, and long-distance environments. The paper concludes with a discus-sion on the need to unravel the relationships between retail activity and non-motorised accessibility, in order to reach sustainable planning goals, as well as the potential usefulness of RMEs for transport policy-making.

\section{Introduction}

The complex relationships between land use and transport has received considerable attention in academic literature (Banister, 2005; De Vos and Witlox, 2013; Ewing et al., 2016). The dominant view is that the benefits of mobility increase if land use and transport are reciprocally supportive, which is associated with the principles of New Urbanism (USA) and the compact city (Europe). The emerging long-standing body of theories and practical applications emphasises the effect of the land use and transport binomial on: (i) human health (Andrews et al., 2012; Wang et al., 2016); (ii) travel behaviour (Lamíquiz and López-Domínguez, 2015; Schwanen et al., 2001; Van Acker and Witlox, 2010; van Wee, 2011; Witlox, 2007); and (iii) environmental issues such as noise and air pollution (Mat Yazid et al., 2011; Loo et al., 2015).

The need to translate academic empiricism into practice has provided multiple planning concepts with different levels of real-life applicability (e.g., Transit Oriented Development, accessibility-based planning, etc.). The analytical concept of "mobility environment" as a planning concept is also a case in point. Inspired by Bertolini and Dijst

\footnotetext{
* Corresponding author.
}

E-mail addresses: arranz@unizar.es (A. Arranz-López), julio.soria-lara@upm.es (J.A. Soria-Lara), cle@unizar.es (C. López-Escolano), apueyo@unizar.es (Á. Pueyo Campos).
(2003), mobility environments are places where land use and transport are reciprocally interrelated in a specific way (Soria-Lara et al., 2015). Mobility environments can be used for both understanding how transport and land use are mutually connected and for developing planning criteria (Soria-Lara et al., 2016; Talavera-Garcia and Soria-Lara, 2015 or Zandvliet et al., 2008). The concept of mobility environments in transport practice, therefore, has enhanced the understanding of how land use and transport are affecting urban congestion, air pollution, noise, and walkability. While mobility environments traditionally focus more on the relationships between motorised transport modes and residential areas in cities and regions, limited attention has been paid to how retail activity interacts with non-motorised transport modes at city level as well as the resulting impact on daily mobility.

The argument behind the proposed identification and mapping of Retail Mobility Environments (RMEs) at city level, as well as their implications for policy-making, builds on the idea that an adequate combination of both retail activity and non-motorised accessibility can yield beneficial impacts on trip frequency, choice of destinations (Iacono et al., 2010), modal shift (Cerin et al., 2007), location of socialization places (Evans, 2009), and improved health of mobile populations (Ståhle et al., 2005; Tight et al., 2011).

This paper seeks to explore the following research question: How can RMEs, as a conceptual framework integrating retail activity and nonmotorised accessibility, be identified and mapped at city level? The city of 
Zaragoza, a representative example of a compact-city model in the Spanish context, serves as the case study. A compact-city environment provides a good study area for two main reasons. First, the relevance of non-motorised accessibility is presumably higher than in other less compact urban contexts. Second, retail activity also tends to be more complex, in terms of diversity (variety of retail activity) and spatial location, than in other built environments. A quantitative methodology was employed to identify and map RMEs in Zaragoza, combining georeferenced data and a survey to citizens.

In the remainder of the paper, Section 2 presents a theoretical discussion on the concept of RME, including the working hypothesis. Section 3 describes the case study. Section 4 outlines the research design, while Section 5 presents the main results. Finally, Section 6 covers the concluding remarks and the implication of RMEs for policy-making.

\section{What makes a retail mobility environment?}

This section reviews the traditional approaches to analysing retail activity and non-motorised accessibility at city level, further distilling a working hypothesis for identifying and mapping RMEs. ${ }^{1}$

\subsection{Non-motorised accessibility}

There is a growing concern regarding how non-motorised accessibility has been measured over the last decades (van Wee, 2016), focusing on the strong limitations posed by the absence of high-quality data on non-motorised movements (Iacono et al., 2010; Roig-Tierno et al., 2013) as well as the limited attention paid to bicycling (Vale et al., 2015). In the context of this research, non-motorised accessibility refers to the physical capacity to reach retail activity by both walking and bicycling. While a wide range of methods are used to measure nonmotorised accessibility (Clarke et al., 2002; Jaskiewicz et al., 2016; Kang, 2015; Lee and Hong, 2013; Negron-Poblete et al., 2014; Vale et al., 2015), here the focus is on place-based and centrality approaches.

In place-based methods, transport studies rely primarily on gravitybased indicators (Miller, 2005). Their distinctiveness lies in estimating the cost for reaching different urban activities according to an impedance function (Vale et al., 2015), based on the time or distance that people are willing to travel. Studies conducted by Kockelman (1997) and Iacono et al. (2010) highlight that the impedance function form to measure non-motorised accessibility should vary depending on trip purpose (e.g. working, shopping, etc.). lacono et al. (2010) used a gravity-based measure as a baseline to illustrate the integral accessibility of different urban activities by non-motorised modes. Scott and Horner (2008) also applied a gravity-based model to evaluate accessibility of several types of urban activities by different socio-economic groups. The authors sought to define and locate places with a social exclusion risk. The gravitybased approach has also been applied to assess bicycling accessibility. For example, Lowry and Callister (2012) developed a gravity-based method to assess the quality of bicycle travel, following a scheme based on impedance function similar to functions used in walking studies.

Centrality-based approached are fundamentally based on topological relationships, without taking into consideration origins and destinations of mobile population. They complement traditional gravity-based indicators, providing additional insights into how accessibility is understood and perceived. Specifically, centrality-based measures provide key information about street features and retail hierarchy. The study carried out by Porta et al. (2009) examined the relationships between street centrality and densities of retail activities in Bologna, Italy,

\footnotetext{
1 To elaborate this section, relevant academic articles were systematically reviewed by conducting two searches of the Scopus database using keywords such as non-motorised, accessibility, retail activity, and commerce. The literature selection used two filters: (i) publications covering local and regional spatial scales; and (ii) publications using different methodological approaches to study both retail activity and non-motorised accessibility at city level.
}

revealing that "betweenness" and "closeness" indicators are highly correlated with larger retail densities. Wang et al. (2014) also examined the location patterns of various retail stores in Changchun, China, finding that street centrality and location advantage are highly correlated.

\subsection{Retail activity}

Retail activity patterns are extensively explored in the literature. Retail density, diversity, and proximity are the traditional indicators used for the assessment of retail activity (Teller and Elms, 2010). These studies usually focus on the definition of market area boundaries (Lee and Lee, 2014) or the attractiveness valuation of retail places (Teller and Reutterer, 2008), among other characteristics.

Regarding retail density, Marashi-Pour et al. (2015) explored the association between tobacco outlets density, socio-economic status and proximity of secondary schools. They used a kernel density estimation, signalling correlations between tobacco outlets, disadvantaged neighbourhoods and the proximity to secondary schools. The study conducted by Roig-Tierno et al. (2013) used retail density to determine potential places for locating a new supermarket in Murcia, Spain. The authors combined kernel density of current supermarkets (geocompetition) and kernel density of population (geodemand), finding that the combination of both kernel densities delivered the best locations for supermarket activity.

Indicators traditionally used in ecological studies (e.g. ShannonWeaver, Simpson or Ullman-Dacey), have been applied to retail diversity. Aguilera Ontiveros and Bárcenas Castro (2014) calculated ShannonWeaver indicator in San Luis Potosí, Mexico, metropolitan area to analyse the correlation between retail diversity and employment opportunities. Higher diversity values indicated places that are more attractive for visitors (Kärrholm et al., 2014) and resilient (Wrigley and Dolega, 2011). However, other methods, such as counting different type of stores in a search radius have also been used. For example, NegronPoblete et al. (2014) calculated diversity (within a $500 \mathrm{~m}$ radius) as a complementary measure to pedestrian accessibility for ageing people in three areas of the greater Montreal, Canada.

Finally, retail proximity is the third indicator to be presented. The most common approach is studying the number and proximity of shops to households and jobs within a given distance. However, in this research, the concept of retail proximity would be closer to the fragmentation approach, i.e. contiguity between retail stores in a specific place. For example, Rotem-Mindali (2012) studied retail activity fragmentation in metropolitan areas, with the aim of uncovering opportunities to increase connectivity and accessibility by both private car and public transport. His findings suggested that higher retail fragmentation requires the use of private cars as complementary modal choice.

\subsection{A working hypothesis to identify and map RMEs}

The basic hypothesis underlying this research is that the RME can provide a comprehensive understanding of the relationships between retail activity and non-motorised accessibility at city level, as well as deliver valuable inputs in the policy-making process.

To identify RMEs in the case study, the central idea focuses on confronting the two sides of the spectrum: non-motorised accessibility and retail activity. This facilitates to distinguish at least four basic RMEs (Fig. 1):

i) Short-distance environments: high values for both retail activity and non-motorised accessibility, resulting in lively places where motorised modes are not essential and walking/bicycling is recurrent for covering shopping activities. On the one hand, indicators based on non-motorised accessibility would reveal places well-connected by a non-motorised network, as well as places highly accessible by walking and bicycling from anywhere within the case study. On the other hand, indicators based on 


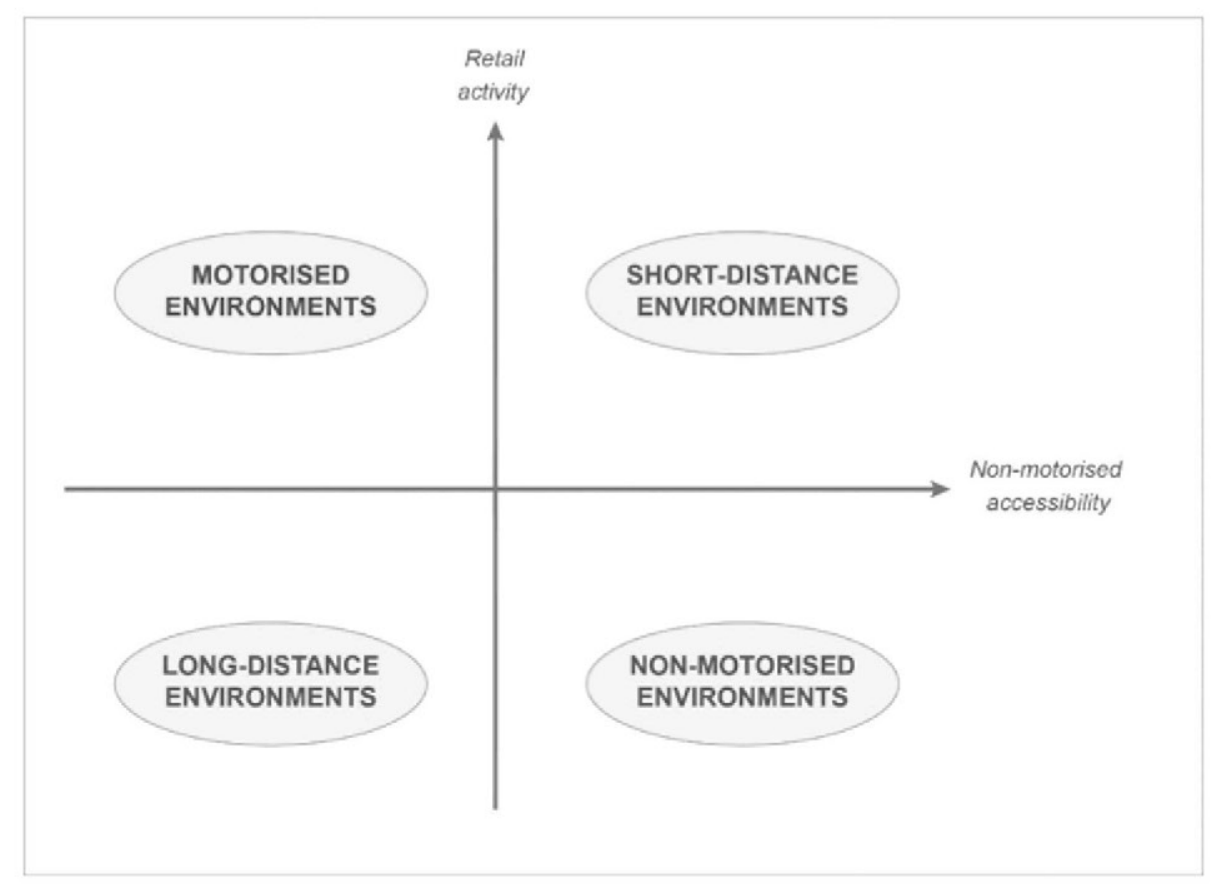

Fig. 1. Working hypothesis.

retail activity would show a complex organization of stores in terms of high levels of both stores contiguity and diversity of stores typologies (e.g. food, clothes, and luxury).

ii) Non-motorised environments: low values for retail activity and high values for non-motorised accessibility, resulting in places where non-motorised modes are predominant. First, indicators focused on non-motorised accessibility would reveal places where motorised transit is almost inexistent. This means good connections by walking and bicycling routes. Second, indicators focused on retail activity would show places where it is hard to find retail stores. Consequently, non-motorised environments would be places totally orientated towards non-motorised transit such as parks, boulevards, etc.

iii) Motorised environments: high values for retail activity and low values for non-motorised accessibility, resulting in places with high density levels of retail stores and where motorised modes are essential for covering shopping activities. First, indicators focused on non-motorised accessibility would reveal places with high parking availability, as well as places not easily accessible by non-motorised modes. Second, indicators based on retail activity would show a complex organization of stores in terms of high levels of both stores contiguity and diversity of stores typologies (e.g. food, clothes, and fashion).

iv) Long-distance environments: low values of both retail activity and non-motorised accessibility, resulting in lonely places where non-motorised modes are inoperative and motorised transport is consequently essential for covering shopping activities. On the one hand, indicators based on non-motorised accessibility would reveal places poorly connected by a non-motorised network. However, those places would have high accessibility levels by motorised modes, fundamentally by car. On the other hand, indicators based on retail activity would show isolated stores with very low diversity of stores typologies.

Fig. 1 represents a simplification of a more complex reality, and our empirical analysis takes this complexity into account. Identifying the predominant RMEs in each place of the case study will provide additional information on how retail activity and non-motorised accessibility are intrinsically related.

\section{Case study: Zaragoza}

Zaragoza, a city of 665,000 inhabitants in north-eastern Spain, has undergone a significant urban transformation over the last 15 years, driven by both population growth and real estate development. However, despite this continuous growth, high urban compactness levels predominate (Calvo Palacios et al., 2011; García Martín, 2016).

Guided by a clear goal to promote non-motorised daily journeys, local institutions have introduced significant changes over the last years (Pueyo-Campos et al., 2016), such as the renewal of the historic centre, the pedestrianisation of streets with high retail density, the implementation of a Light Rail Transit system and the enlargement of the bicycle lane network (Fig. 2).

Nevertheless, the development of shopping centres in suburban areas - fundamentally car-oriented projects - is also taking place in $\mathrm{Za}$ ragoza, leading to the creation of new urban sub-centres for leisure and shopping activities. These new retail loci can pose a threat to traditional retail activity in old neighbourhoods and the city centre (Pueyo Campos, 2007). To forestall this potential conflict, local institutions are promoting local and proximity retail activity through specific policies such as the new Local Supporting Plan of Proximity Commerce ${ }^{2}$ or the initiative Zaragoza ShopIn Area. ${ }^{3}$ Given this context, RMEs can help identify and map places where retail and non-accessibility policies should be implemented and promoted.

\section{Research design}

The identification and mapping of RMEs in Zaragoza entailed the following steps (Fig. 3):

Step 1: operationalisation of non-motorised accessibility indicators (walking, bicycling and betweenness of retail activity), identifying different Accessibility Zones (AZs);

\footnotetext{
${ }^{2}$ https://goo.gl/OfZuvj

${ }^{3} \mathrm{http}: / / \mathrm{goo} . \mathrm{gl} / \mathrm{CGeA0D}$
} 

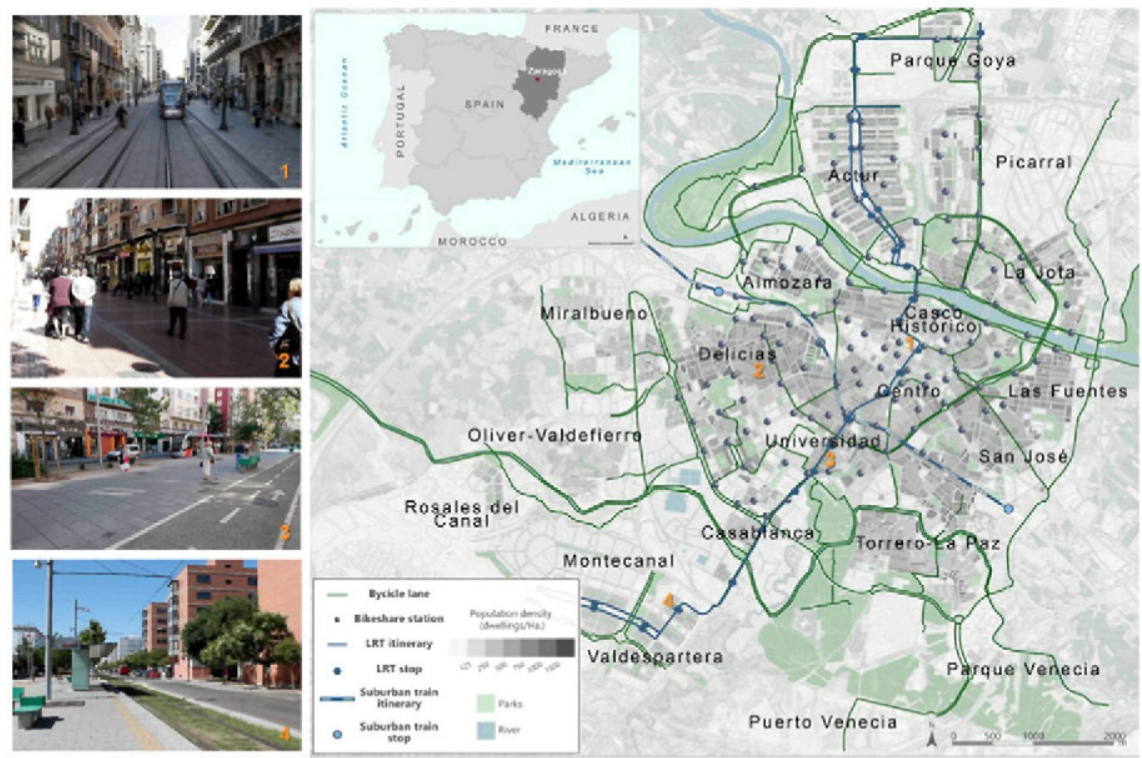

Fig. 2. Zaragoza location map.

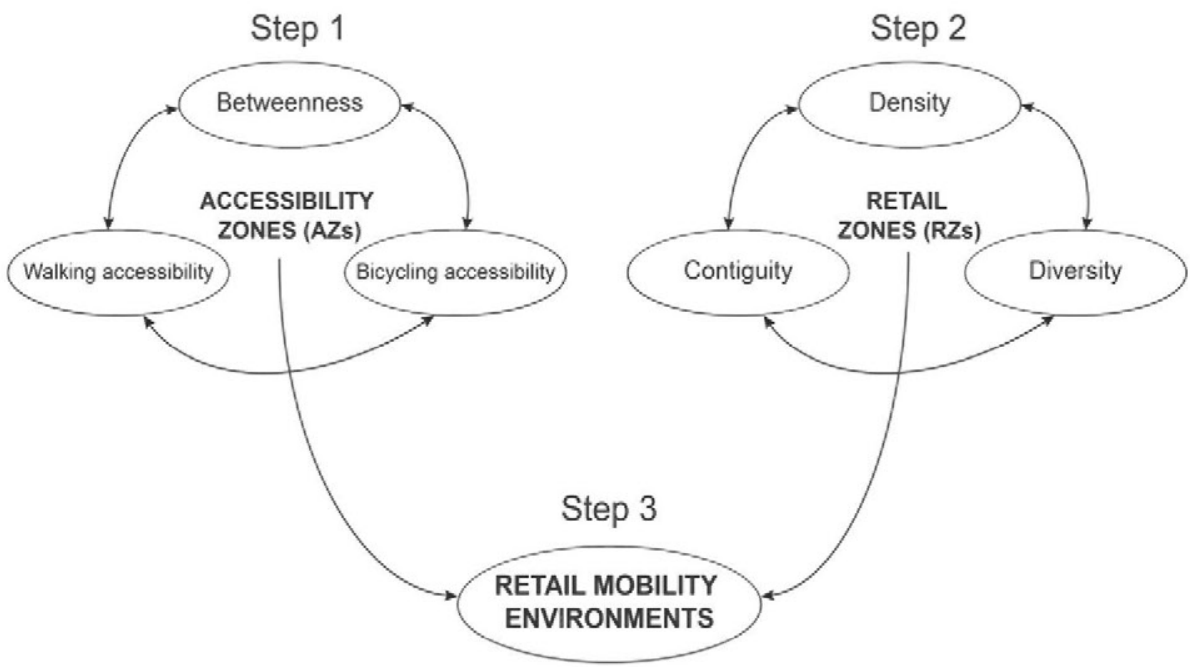

Fig. 3. Methodological scheme.

Step 2: operationalisation of retail activity indicators (retail density, retail diversity and retail contiguity), identifying different Retail Zones (RZs);

Step 3: combining the results from Step 1 and 2 to obtain the four types of RMEs described in the working hypothesis (Section 2.3).

\subsection{Data}

A $100 \mathrm{~m} \times 100 \mathrm{~m}$ grid, adapted from the European Environment Agency, ${ }^{4}$ was used to integrate the information. For accessibility calculations, a street network from the Spanish National Centre of Geographic Information ${ }^{5}$ was used, while the bicycle lane network came from the Zaragoza City Council open data website ${ }^{6}$. Both databases were recently updated. Furthermore, retail locations were digitised from a 2015 database developed by the Spanish Ministry of Economy ${ }^{7}$, and cross-

\footnotetext{
${ }^{4}$ goo.gl/iaagdV

5 http://goo.gl/ZLePqU

6 https://goo.gl/BTXe16

http://goo.gl/xc3Wva
}

checked with information from telephone directory listings and retail corporate websites, yielding $>3000$ retail stores.

Also the data collected via a questionnaire, disseminated through both internet and fieldwork (April-June 2016), allowed the weighing of non-motorised accessibility and retail activity indicators ${ }^{8}$ as well as the calculation of impedance functions ${ }^{9}$ (see Sections 4.2 and 4.3 below). In total, 384 answers were collected, a $95 \%$ confidence interval with a bias of $5 \%$ in the context of the case study. The questionnaire played an important part in the study, as information on non-motorised modes is usually very limited compared to databases on motorised transport (Southworth, 2005).

\footnotetext{
${ }^{8}$ To indicate preferences between indicators, citizens were encouraged to compare peers of indicators. Non-motorised indicators and retail activity indicators were processed separately. An example of question to compare preferences on indicators is the following: "Do you prefer reaching retail stores by walking or by bicycling?". This question is a translation into English from the original in Spanish.

${ }^{9}$ An example of question to elaborate the impedance functions is the following: "Independently of the neighbourhood where you are currently living, how much time are you willing to spend to reach daily retail stores by walking?". This question is a translation into English from the original in Spanish.
} 
Table 1

Accessibility Zones indicators.

\begin{tabular}{|c|c|c|c|}
\hline $\begin{array}{l}\text { Accessibility } \\
\text { Indicators }\end{array}$ & Equation & Units & Description \\
\hline $\begin{array}{l}\text { Walking } \\
\text { accessibility }\end{array}$ & $A_{i}=\sum_{d w i}\left(\Sigma_{j \neq i} E_{j} e^{-\beta x_{i j}}\right)$ & $\begin{array}{l}\text { Time } \\
\text { (minutes) }\end{array}$ & $A_{i} \geq 0$ \\
\hline $\begin{array}{l}\text { Bicycling } \\
\text { accessibility }\end{array}$ & $\begin{array}{l}\text { where } A_{i} \text { is the accessibility for zone } i ; d w i \text { are the three retail } \\
\text { typologies; } x_{i j} \text { is the travel time between zones } i \text { (origin) and } j \\
\text { (destination), } E_{j} \text { is the number of shops in } j \text { and } \beta \text { is a parameter of the } \\
\text { impedance function. }\end{array}$ & & $\begin{array}{l}\text { It represents the availability of retail activity in each cell and the } \\
\text { willingness of citizens (in time) to reach them. The results for each cell } \\
\text { were respectively called Walking Accessibility Zones (WAZs), and } \\
\text { Bicycling Accessibility Zones (BAZs). The time between origins and } \\
\text { destinations have been calculated by using GIS, taking account two core } \\
\text { elements: (i) the length of the street; (ii) the walking speed's average } \\
\text { ( } 4 \mathrm{~km} / \mathrm{h} \text { according to literature; e.g. Marquet and Miralles-Guasch, } \\
2014 \text { ) and the bicycling speed's average ( } 12 \mathrm{~km} / \mathrm{h} \text { according to the } \\
\text { bicycle's barometer for Spain). }\end{array}$ \\
\hline Betweenness & $\begin{array}{l}B_{i}=\sum_{j, k \in G-\{i\} ; d[j, k] \leq r} \frac{n_{j k}[i]}{n_{j k}} \times W[j] \\
\text { where } B_{i} \text { is the betweenness for each retail store }(i) ; n_{j k} \text { is the number of } \\
\text { shortest paths from retail } j \text { to retail } k \text { in } G \text { (study area); } \\
n_{j k}[i] \text { is the subset of these paths that pass through } i, \text { with } j \text { and } k \text { lying } \\
\text { within the network radius } r \text { from } i\end{array}$ & one & $\begin{array}{l}B_{i} \geq 0 \\
\text { It provides information about the topological relationship between retail } \\
\text { activity and the street/bicycle network. It does not have units. Larger } \\
\text { values mean a better location for retail. The results for each cell was } \\
\text { called Betweenness Zones (BeZs). }\end{array}$ \\
\hline
\end{tabular}

\subsection{Step 1: Accessibility Zones (AZs)}

Three indicators were used to identify AZs (Table 1): (i) walking accessibility; (ii) bicycling accessibility; (iii) betweenness. A gravitybased model was used for indicators on walking and bicycling, meaning that each accessibility indicator has two components: the number and distribution of retail shops in each destination area, and an impedance function, which represents the willingness of citizens to reach retail places by walking and bicycling. Those impedance functions were empirically calculated for both walking (Fig. 4) and bicycling (Fig. 5) from the questionnaire described in Section 4.1. Three retail categories were used:

Daily retail: everyday activities such as small fishmongers, greengrocer, bakeries, bars, supermarkets, etc.

Weekly retail: activities that people usually carry out once or twice a week or every couple of weeks, like hairdresser, pharmacy, gym, etc.

Incidental retail: monthly or less frequent activities, like fashion and accessory purchases, travel agency visits, cell phone shops, home products stores, etc.

While literature has evidenced how the slope can have influence on the willingness of people to reach destinations by walking and bicycling (Lee and Moudon, 2004), this is not relevant in the present study due to Zaragoza is a flat city. For this reason, the slope has not been considered to estimate the impedance functions.

Finally, "betweenness" indicator refers to the likelihood of citizens can find retail stores on the route towards their shopping destinations. The indicator was processed by the Urban Network Analysis (UNA) toolbox (designed to ArcGIS 10 or later). It is based on topological relationships where road segments are the links and retail activity represent nodes. A search radius was not considered to provide a view of how each retail store interacts with each other without physical boundaries.

The three abovementioned indicators were measured at city level as the average value of each indicator in a $300 \mathrm{~m}$ service area. To do this, service areas were calculated from each AZ centroid around the network. This "influence threshold" of $300 \mathrm{~m}$ was chosen according to the optimal distance to basic amenities as defined by Agenda 21.

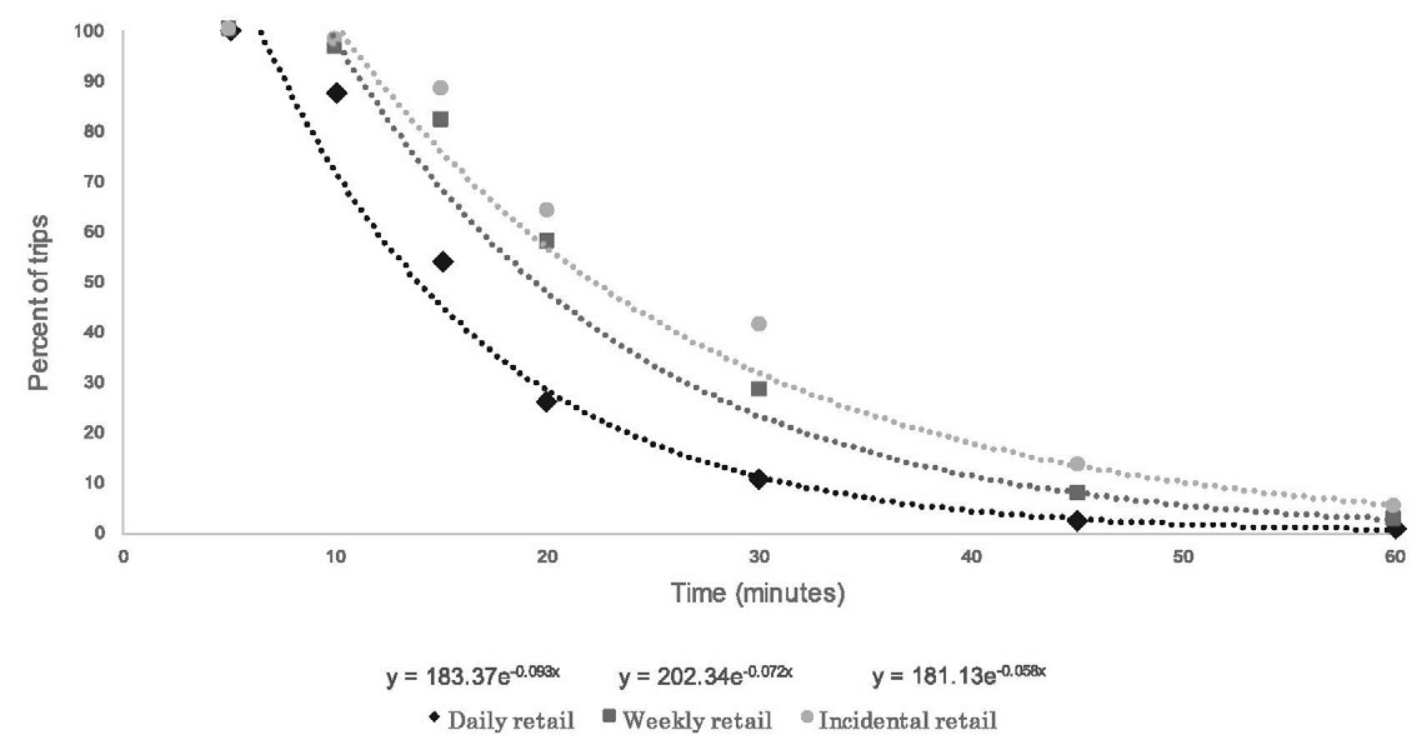

Fig. 4. Impedance functions for walking. 


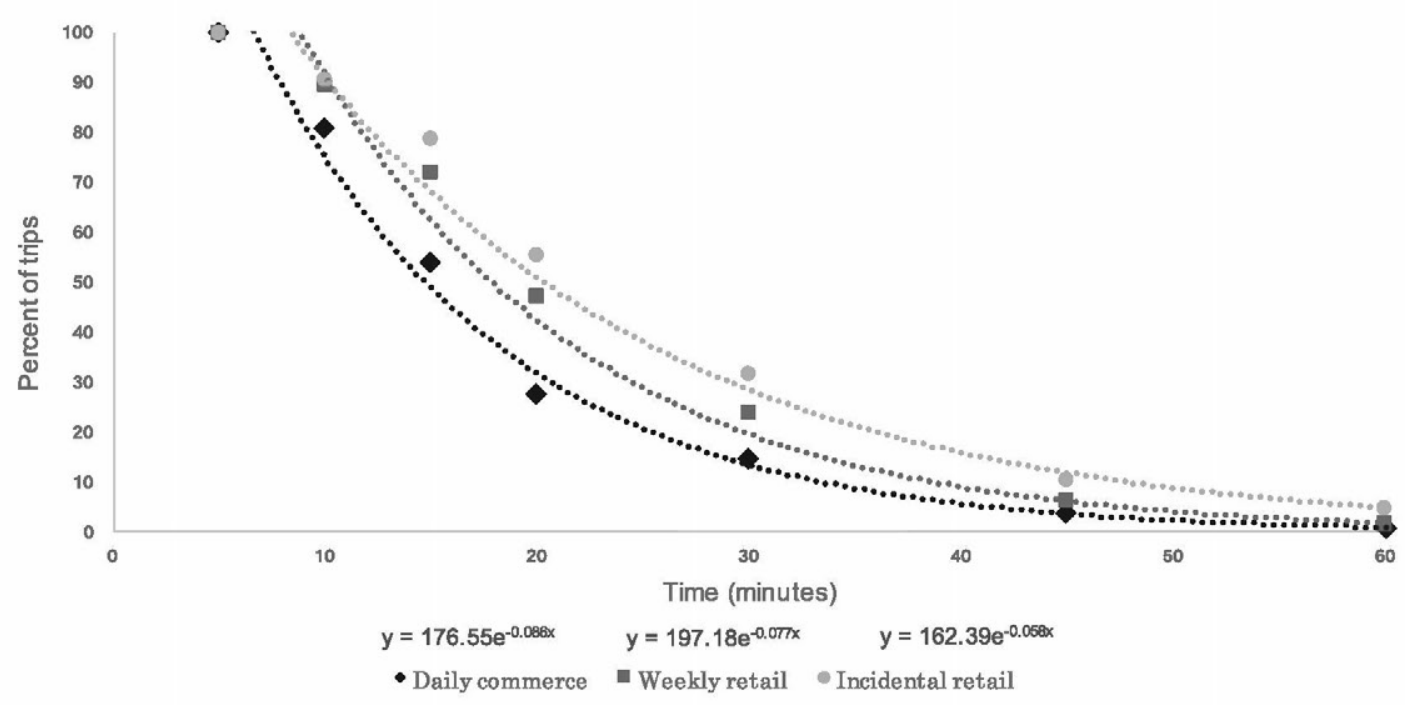

Fig. 5. Impedance functions for bicycling.

\subsection{Step 2: Retail Zones (RZs)}

RZs were defined using the following three indicators (Table 2): (i) retail density, the number of retail opportunities in a specific area; (ii) retail diversity, the likelihood of finding different types of retail stores in a specific place; (iii) retail contiguity, the distance between retails stores. Indicators of retail activity were also measured as the average of the RZs in a $300 \mathrm{~m}$ service area.

\subsection{Step 3: Identification and mapping of RMEs}

This final step involved the aggregation of the results from Step 1 and 2; standardised AZs and RZs indicators were calculated using a min-max normalization method:

$S=\frac{x-\operatorname{Min}}{\operatorname{Max}}$

where $S$ is the standardised value; $x$ is the indicator value, Min is the lowest value, and Max is the highest value of the index.

The results obtained in steps 1 and 2 were aggregated using multicriteria techniques, specifically, the Analytic Hierarchy Process (AHP) developed by Saaty (1987). This allowed separate weighing of each of the three indicators from non-motorised accessibility and from retail activity (Table 3).

Four mobility environments were identified in the case study, according to the scheme represented in Section 2.3 (working hypothesis),
Table 3

Weight for each indicator by using the AHP process.

$\begin{array}{llll}\text { AZ indicator } & \text { Weight } & \text { RZ indicator } & \text { Weight } \\ \text { Walking accessibility } & 0.69 & \text { Density } & 0.35 \\ \text { Bicycling accessibility } & 0.18 & \text { Diversity } & 0.43 \\ \text { Betweenness } & 0.13 & \text { Contiguity } & 0.22\end{array}$

by combining the mean values of the aggregated results. Separately, the ratio between AZs and RZs was used to map the intensity of each RME in Zaragoza.

\section{Results}

\subsection{Accessibility Zones}

Accessibility Zones are illustrated in three maps in Fig. 6. Walking accessibility is the combination of the time that people are willing to travel by foot to reach retail activity, weighted by the retail activity in each destination. Each cell $(100 \mathrm{~m} \times 100 \mathrm{~m})$ for the walking accessibility computation is called Walking Accessibility Zone (WAZ). The mean value of this indicator was 0.036 , and in total $25.65 \%$ of WAZs values were higher than the mentioned mean value. The highest values were found in the city centre and in the heart of the oldest neighbourhoods (San José, Las Fuentes, Almozara, Torrero-La Paz, Delicias or Actur). This is explained by the well-connected street network and the existence

Table 2

Retail Zones indicators.

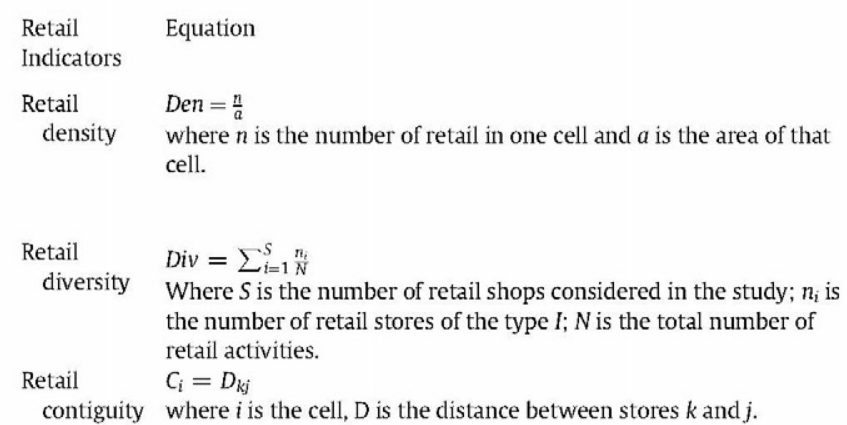

Units Description

Shops per

hectare

None

It represents the intensity of retail activity in each cell. It does not take accoun retail typology and increases as the number of stores increase. The results for each cell was called Density Zone (DZ).

Div $\geq 0$

It represents the number of different type of retail in each cell. It increases as the variety of retail increase. The results for each cell was called Diversity Zone (DiZ). 


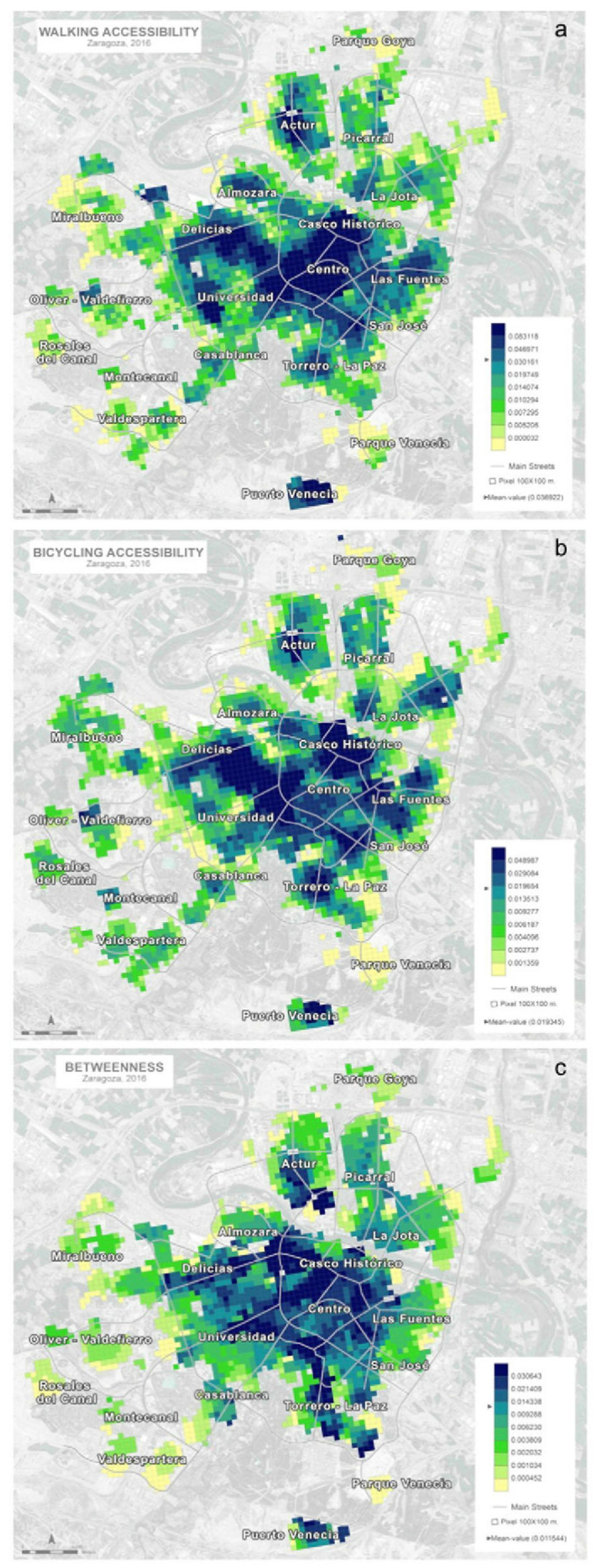

Fig. 6. Accessibility Zone indicators: a) walking accessibility, b) bicycling accessibility, and c) betweenness. of a consolidated daily retail activity based on markets, bakeries, greengrocers and stationery shops. The lowest values were in the newest neighbourhoods such as Valdespartera, Rosales del Canal or Parque Venecia. In these neighbourhoods medium and large retail areas dominate, with consequences such as fewer suppliers, longer distances between retail stores and the need for motorised modes for travelling.

The second indicator was bicycling accessibility. In this case, every cell ( $100 \mathrm{~m} \times 100 \mathrm{~m}$ ) for the bicycling accessibility computation, called Bicycling Accessibility Zone (BAZ), indicates the time that people are willing to travel by bicycle for shopping, weighted by the retail activity in each destination. The mean value of this indicator was 0.018 , and in total $30.38 \%$ of BAZs were higher than the mentioned mean. Again, highest values were found in the city centre and in the heart of the oldest neighbourhoods. Nonetheless, this indicator was strongly influenced by the presence or absence of bicycling lanes. This fact can be observed in some places such as Centro or Las Fuentes, where high values are more fragmented due to the lack of continuous bicycle paths.

Finally, the indicator betweenness was the third to be considered. Each cell, Betweenness Zone (BeZ), denotes the potential of passersby at different retail stores on the non-motorised network or the ease of people to find other stores in their shopping pathway. Its mean value was 0.01 , and in total $33.26 \%$ of BeZs were higher than the mean. Unlike with the AZs indicators, higher values for this indicator can be found at both the city centre and the older neighbourhoods. However, lower values close to the city edge (e.g. Valdespartera, Miralbueno, Parque Goya, Oliver-Valdefierro or Parque Venecia, among others), are larger than in the previous indicators. This can be explained by two factors: (i) street network morphology; and (ii) the existence of retail activity. The first factor is related to the lower complexity and connectivity of the street network in the new neighbourhoods. The second factor can be explained by the limited presence of retail activity, due to the lack of buildings with double function: residential and retail. Also, these neighbourhoods are sparsely populated, and in some cases traditionally poor and socially neglected.

Finally, at methodological level, it should be highlighted that the results for each accessibility indicator show a street network "barrier effect" in the edges of the city.

\subsection{Retail Zones}

The study of RZs is illustrated through the three maps represented by Fig. 7. Density Zones (DZs) were obtained from the retail density indicator (measured in retail stores per hectare). The mean value was 0.035 , and $31.07 \%$ of DZs were higher than the mentioned mean. Three cases of high DZ values were distinguished: (i) the city centre, due to the great presence of franchise shops (mainly clothes) and specialist retailers such as jewelleries, real-state agencies, leisure, and bookshops; (ii) old neighbourhoods (Delicias, Las Fuentes or Torrero-La Paz), which have a stronger presence of daily retailers; and (iii) the two main shopping centres, located in Actur and Puerto Venecia. Low values were found in new neighbourhoods (Valdespartera, Rosales del Canal, Miralbueno and Parque Goya). In these places, buildings and retail activity are grouped in the main streets, and the use of motorised modes is common.

The second indicator to be studied was the retail diversity, resulting in Diversity Zones (DiZ), representing the number of different types of retail stores in each cell. The mean value for this indicator was 0.217 , and $41.54 \%$ of Dizs were higher than the mean. The spatial distribution of high and low values was very similar to DZs. Again, three diversity patterns appeared: (i) in the city centre, with clothes franchise shops at main streets and traditional retail stores on side streets (this is complemented by a homogeneous distribution of food chains and leisure, and some specialised food retail); (ii) in old neighbourhoods, which show diverse daily food retail; and (iii) shopping centres (mainly Puerto Venecia), where many retail chains (clothes, food, leisure, DIY superstores) can be found in a relatively small area. Despite the high 


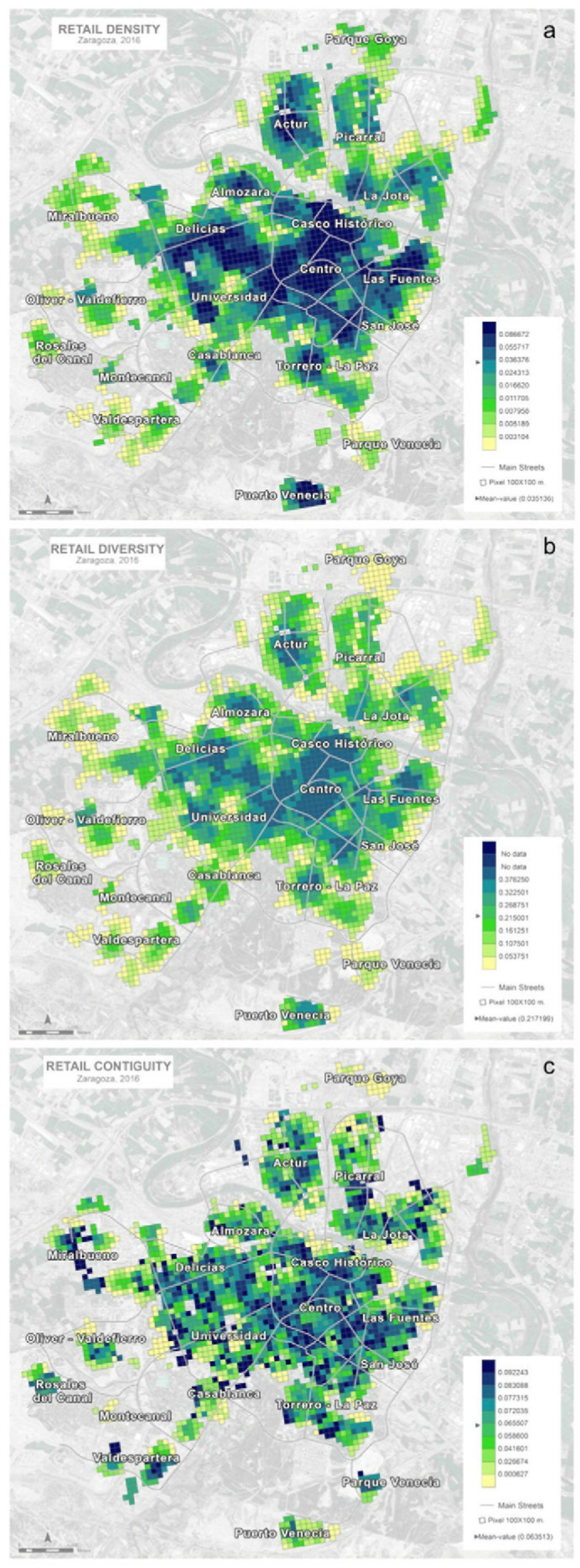

Fig. 7. Retail Zone indicators: a) retail density; b) retail diversity, and c) retail contiguity. values, regular access by walking or bicycling only occurs in the first two.

The third indicator to be analysed was retail contiguity, indicating the distance between retail opportunities along the network. In this case, every cell was called Contiguity Zone (CZ). With a mean value of 0.053 , in total $56.43 \%$ of $C Z$ s had higher values than the mean. The different values of this indicator were homogenously distributed in the case study. This result can be explained by the spatial distribution of retail activities, which tend to group close to each other, especially small retailers. Some interesting examples are found in Valdespartera, Rosales del Canal and Miralbueno.

\subsection{Retail Mobility Environments}

The distribution of RMEs in Zaragoza is shown in Fig. 8. RMEs were computed by combining both the three non-motorised accessibility indicators (AZs) and the three retail indicators (RZs). According to the working hypothesis, detailed in Section 2.3, a total of four RMEs were identified and mapped in the case study: i) short-distance environments, ii) non-motorised environments, iii) motorised environments, and iv) long-distance environments. They were identified by using mean values of AZs $(\bar{x}=0.077)$ and RZs $(\bar{x}=0.305)$ as thresholds (Fig. 8b). The long-distance environment is the most predominant in the case study, represented by a total of $51.30 \%$ of the analysed cell, followed by the short-distance environment (29.20\%), the motorised environment (17.93\%), and the non-motorised environment (1.67\%).

The short-distance environment was characterised by high AZs and RZs values, mainly located in the oldest and traditional neighbourhoods with high or very high population densities ( $\geq 750-1000$ dwellings/Ha.). They were places where daily, occasional and incidental retail activity can be easily found. Two examples of relevant mobile patterns could be identified in short-distance environments: (i) in the city centre (Casco Histórico and Centro), and (ii) in old neighbourhoods. In the city centre, people rely on motorised modes (private or public transport), while within the RME they usually travel by foot or bicycle. It is frequently used by populations from the entire city for incidental and some weekly purchases, but also daily retail is present for meeting the basic needs of residents. Old neighbourhoods (e.g. Las Fuentes, San José, Delicias, Almozara and Torrero-La Paz) are mainly used by resident population for daily purchases (e.g. bakery, greengrocer, market, bars), and access and travel are predominantly by foot. However, within this second example, the role of Gran Casa shopping centre, located in the middle of Actur should be highlighted. It is the second largest shopping centre in the city and also functions as a place for daily purchases for residents due to the lack of retail activity in the rest of the neighbourhood. Ultimately, retail activity is widely covered in the short-distance RME.

The second type of RME, the non-motorised environment, was characterised by high values for AZs and low values for RZs. In those environments, residential buildings were inexistent. In Zaragoza, those places are identified with parks, or public amenities such as Aljafería Palace, the bullring or the university campus. In the case of parks, users are predominantly neighbourhood residents, who rely on walking or bicycling. However, the public amenities are used by the entire city population. Retail activity are hardly covered in this RME.

The third type of RME, the motorised environment, was characterised by low values for AZs and high for RZs. It could be considered a transition area between short-distance and long-distance environments. In these places, the density of dwellings was between 500 and 750 dwellings/Ha., and occasional and incidental retail dominate. Residents could cover their daily needs, but in many cases required motorised modes. Some examples are neighbourhoods where small retailers are underrepresented, such as Valdespartera or La Jota, where the main supermarkets are located in the western edge and in the middle of the neighbourhood, respectively. Ultimately, they are suitable places to promote "park and ride". 

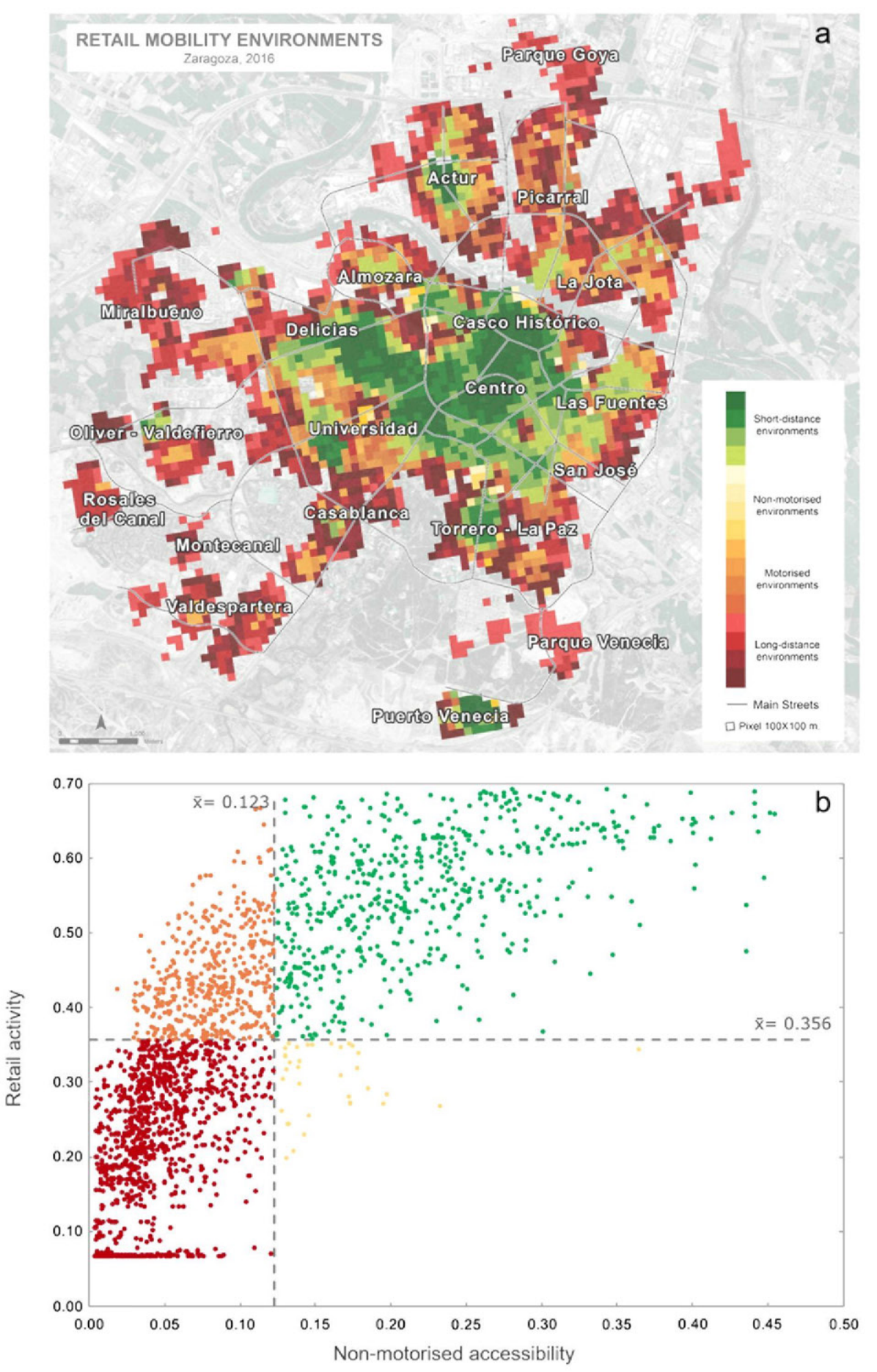

Non-motorised environment - Motorised environment · Long-distance environment - Short-distance environment

Fig. 8. a) Spatial distribution of Retail Mobility Environments b) Distribution of RMEs according to the mean value of non-motorised-accessibility and retail activity indicators.

The fourth RME, the long-distance environment, was characterised by both low AZs and RZs values as well as low population densities ( $<250$ dwellings/Ha.). Regarding its spatial distribution, two large locations can be seen: (i) the edge of old neighbourhoods such as Las Fuentes, San José, Torrero-La Paz, Casablanca, Delicias and Montecanal; and (ii) new urban developments such as Miralbueno, Valdespartera, Rosales del Canal or Parque Venecia. Both locations are residential areas close to ring roads, and in most cases motorised modes are required for reaching retail activity (e.g., in the south neighbourhoods such as Valdespartera, Rosales del Canal and Parque Venecia). Despite the abundance of pedestrian streets for leisure, reaching retail to cover daily needs usually requires motorised trips. This RME is primarily used by local residents, who most of the time need motorised transport modes to cover their commercial needs.

\section{Discussion and conclusions}

The paper sought to answer the following research question: How can RMEs, as a conceptual framework integrating retail activity and nonmotorised accessibility, be identified and mapped at city level? The 
theoretical assumptions were applied in the context of Zaragoza, a compact city in north-eastern Spain. A compact environment was selected for developing this particular method for mapping RMEs, due to the research's focus on non-motorised accessibility (walking and bicycling). The methodological approach used quantitative tools, including a citywide survey, to gain insights into the willingness of the population to reach retail activity by non-motorised transport modes. After analysing the obtained results, two main aspects need to be discussed in-depth: (i) the unexplored relationship between retail activity and nonmotorised modes, and (ii) the implications of RMEs for transport policy-making.

\subsection{Retail activity and non-motorised accessibility: an unexplored relationship}

Academic research finds that integrating land use and transport planning at city level can deliver a significant contribution to achieving sustainable planning outcomes (Banister, 2008). The literature traditionally focuses more on studying the relationships between motorised modes and land use activities such as jobs and housing (Cervero and Kockelman, 1997; Ewing and Cervero, 2010; Mattioli, 2014; Wegener and Fuerst, 2004) than on the connections between retail activity and non-motorised accessibility (Marashi-Pour et al., 2015). However, in the view of this research, focusing mainly on motorised transport and jobs is not sufficient for reaching the sustainable goals postulated by New Urbanism (USA) and the compact city (Europe) principles.

To address this gap, we presented the concept of RME as spatial units where retail activity and non-motorised accessibility are combined in a specific way. We developed a method based on a quantitative approach, built upon the following working hypothesis (Section 2.3; Fig. 1): "Confronting the two side of the spectrum (non-motorised accessibility and retail activity) at least four basic RMEs can be distinguished: (i) Short-distance environments; (ii) Non-motorised environments; (iii) Motorised environments; (iv) Long-distance environments". Three indicators for examining non-motorised accessibility (walking accessibility; bicycling accessibility; betweenness) and three indicators for retail activity (density, diversity and contiguity) were applied to the case of Zaragoza, and their results were processed in different Accessibility Zones (AZs) and Retail Zones (RZs). Finally, the full range of indicators was weighted and combined by using multi-criteria analysis, facilitating the identification and mapping of four RMEs in the case study.

One of the main limitations faced during the research was the absence of information for studying both retail activity and non-motorised accessibility, also highlighted by other authors in the context of studies on non-motorised modes (Southworth, 2005). In particular, most of the information was obtained empirically and digitised for processing, including location of retail activity, network for walking and bicycling, and willingness of citizens to reach retail activity by non-motorised modes. The lack of information on non-motorised transport modes also showed the bias of public information towards motorised transport modes and their impact on daily life.

To gain more insights into the unexplored relationship between retail activity and non-motorised modes, further research should focus on studying and modelling which retail activity factors are significant in daily mobility. Moreover, the comparison of different cases studies can also provide additional findings on how the relationship between non-motorised accessibility and retail activity can explain different levels of urban compactness, and how those findings can be applied in transport policy-making.

\subsection{Implications of RMEs for transport policy-making}

Transport policy is undergoing a substantial transformation, with a marked paradigm shift towards communicative approaches (Bertolini,
2007; Habermars, 2007; Innes and Booher, 2010) - prioritising the transport policy-planning process rather than policy ends as well as conceiving transport policy as a learning process where the coordination of various stakeholders and practitioners must be an essential aspect (Willson, 2001). Given this context, methods and tools that facilitate this transition are required, and RMEs could provide valuable support.

The proposed methodology for identifying and mapping RMEs falls well into the scope of the rational approach, where goals are first set (e.g. reducing daily journey distances). The next step is the selection of policies, including generating and evaluating alternatives. Finally, the last step is the implementation of different actions to achieve the stated goals. Accordingly, RMEs could play an important role across the different phases of this rational policy-making framework. First, RMEs can be crucial for identifying policy goals within a specific spatial context (e.g. goals for short-distance environments, goals for motorised environments, etc.) (Soria-Lara and Valenzuela-Montes, 2014). Second, RMEs can also be an instrument for assessing the suitability and acceptability of selected transport policies, as evidenced by Talavera et al. (2014) in the context of walking mobility environments. Third, RMEs can be used for the spatial application of different policy actions by practitioners (Bertolini and Dijst, 2003).

RMEs also are a promising method in the context of communicative planning, fundamentally as a tool to facilitate communication between the wide range of actors that take part in the transport-policy process. In particular, RMEs could combine "tacit" and "explicit" knowledge in an iterative fashion (te Brömmelstroet and Bertolini, 2008). While explicit knowledge is characterised as easily codified and expressed in words and numbers; tacit knowledge is deeply rooted in personal experience in a specific context, which makes it harder to share. Accordingly, the methods for identifying and mapping RMEs in the context of Zaragoza provided quantitative information, which is more easily understood by traditional transport planners (e.g. standards of retail density, accessibility levels, etc.), as well as qualitative information, which is more familiar to urban planners and the public (e.g. diagnostic maps, spatial boundaries, etc.).

In summary, RMEs can provide a valuable transport policy tool for bridging rational and communicative approaches. Since transport policy is not a purely theoretical endeavour, further research should focus on testing the real usability of RMEs to facilitate a transition from rational to communicative systems, highlighting pros and cons as well as new ways to improve the identification and mapping of RMEs to enhance the link between transport research and policy action. Research designs where practitioners can coproduce new knowledge alongside academics are fruitful approaches for testing the usability of RMEs, for example through controlled experiments or experiential case studies (te Brömmelstroet, 2015).

\section{Acknowledgements}

Authors would like to acknowledge two anonymous referees for their constructive comments, which have improved the earlier version of our manuscript.

This paper has been carried out within the framework of the project "PLOTEG: Herramientas cartográficas para una gobernanza inteligente en las ciudades digitales: Análisis territorial de las condiciones de vida", funded by Ministry of Economy and supported by European Institutions. R\&D Spanish program Grant agreement no. CSO2013-46863C3-3-R

\section{References}

Aguilera Ontiveros, A., Bárcenas Castro, M.A., 2014. Medición de la diversidad comercial minorista en áreas urbanas a través del uso de los índices de Shannon-Weaver y de Ullman-Dacey. Estud. Geol. 75:455-478. 
Andrews, G.J., Hall, E., Evans, B., Colls, R., 2012. Moving beyond walkability: on the potential of health geography. Soc. Sci. Med. 75:1925-1932. http://dx.doi.org/10.1016/j. socscimed.2012.08.013.

Banister, D., 2005. Unsustainable Transport: City Transport in the New Century (London).

Banister, D., 2008. The sustainable mobility paradigm. Transp. Policy 15:73-80. http://dx. doi.org/10.1016/j.tranpol.2007.10.005.

Bertolini, L., 2007. Evolutionary urban transportation planning: an exploration. Environ. Plan. A 39:1998-2019. http://dx.doi.org/10.1068/a38350.

Bertolini, L., Dijst, M., 2003. Mobility environments and network cities. J. Urban Des. 8: 27-43. http://dx.doi.org/10.1080/1357480032000064755.

Calvo Palacios, J.L., Pueyo Campos, A., Zúñiga Antón, M., 2011. La ciudad de Zaragoza en un escenario de crisis: diagnóstico y propuestas territoriales para nuevos paradigmas urbanos. Geographical 47-60.

Cerin, E., Leslie, E., du Toit, L., Owen, N., Frank, L.D., 2007. Destinations that matter: associations with walking for transport. Health Place 13:713-724. http://dx.doi.org/10. 1016/j.healthplace.2006.11.002.

Cervero, R., Kockelman, K., 1997. Travel demand and the 3Ds: density, diversity, and design. Transp. Res. Part D Transp. Environ. 2:199-219. http://dx.doi.org/10.1016/ S1361-9209(97)00009-6.

Clarke, G., Eyre, H., Guy, C., 2002. Deriving indicators of access to food retail provision in British cities: studies of Cardiff, Leeds and Bradford. Urban Stud. 39:2041-2060. http://dx.doi.org/10.1080/0042098022000011353.

De Vos, J., Witlox, F., 2013. Transportation policy as spatial planning tool; reducing urban sprawl by increasing travel costs and clustering infrastructure and public transportation. J. Transp. Geogr. 33:117-125. http://dx.doi.org/10.1016/j.jtrangeo.2013.09.014

Evans, G., 2009. Accessibility, urban design and the whole journey environment. Built Environ. 35:366-385. http://dx.doi.org/10.2148/benv.35.3.366.

Ewing, R., Cervero, R., 2010. Travel and the built environment. J. Am. Plan. Assoc. 76: 265-294. http://dx.doi.org/10.1080/01944361003766766.

Ewing, R., Hamidi, S., Grace, J.B., 2016. Compact development and VMT-environmental determinism, self-selection, or some of both? Environ. Plann. B Plann. Des. 43 737-755. http://dx.doi.org/10.1177/0265813515594811.

García Martín, F.M., 2016. Compacidad y densidad de las ciudades españolas. EURE 42 , $5-27$

Habermars, J., 2007. Classical pragmatism and communicative action. In: Hickman, L.A. (Ed.), Pragmatism as Post-Postmodernism: Lessons from John Dewey. Fordham Univ Press http://dx.doi.org/10.5422/fso/9780823228416.003.0005.

Iacono, M., Krizek, K.J., El-Geneidy, A., 2010. Measuring non-motorized accessibility: issues, alternatives, and execution. J. Transp. Geogr. 18:133-140. http://dx.doi.org/10. 1016/j.jtrangeo.2009.02.002.

Innes, J.E., Booher, D.E., 2010. Planning with Complexity: An Introduction to Collaborative Rationality for Public Policy. Routledge (Taylor \& Francis Group)

Jaskiewicz, I., Block, D., Chavez, N., 2016. Finding food deserts: a comparison of methods measuring spatial access to food stores. Health Promot. Pract. 17:400-407. http://dx. doi.org/10.1177/1524839915610517.

Kang, C.-D., 2015. The effects of spatial accessibility and centrality to land use on walking in Seoul, Korea. Cities 46:94-103. http://dx.doi.org/10.1016/j.cities. 2015.05.006.

Kärrholm, M., Nylund, K., Prieto de la Fuente, P., 2014. Spatial resilience and urban planning: addressing the interdependence of urban retail areas. Cities 36:121-130. http:// dx.doi.org/10.1016/j.cities.2012.10.012

Kockelman, K., 1997. Travel behavior as function of accessibility, land use mixing, and land use balance: evidence from San Francisco Bay Area. Transp. Res. Rec. J. Transp. Res. Board 1607:116-125. http://dx.doi.org/10.3141/1607-16.

Lamíquiz, P.J., López-Domínguez, J., 2015. Effects of built environment on walking at the neighbourhood scale. A new role for street networks by modelling their configurational accessibility? Transp. Res. A Policy Pract. 74:148-163. http://dx.doi.org/10. 1016/j.tra.2015.02.003

Lee, G., Hong, I., 2013. Measuring spatial accessibility in the context of spatial disparity between demand and supply of urban park service. Landsc. Urban Plan. 119:85-90. http://dx.doi.org/10.1016/j.landurbplan.2013.07.001.

Lee, B., Lee, S.-K., 2014. Delimiting boundaries of market areas of central places using the density of retail facilities in an urban space. Int. J. Urban Sci. 18:90-102. http://dx.doi. org/10.1080/12265934.2014.890061.

Lee, C., Moudon, A.V., 2004. Physical activity and environment research in the health field: implications for urban and transportation planning practice and research. J. Plan. Lit. 19:147-181. http://dx.doi.org/10.1177/0885412204267680.

Loo, L.Y.L., Corcoran, J., Mateo-Babiano, D., Zahnow, R., 2015. Transport mode choice in South East Asia: investigating the relationship between transport users' perception and travel behaviour in Johor Bahru, Malaysia. J. Transp. Geogr. 46:99-111. http:// dx.doi.org/10.1016/j.jtrangeo.2015.06.011.

Lowry, M., Callister, D., 2012. Using Bicycle Level of Service to Assess Community-wide Bikeability. 91st Annu. Meet. Transp. Res. Board, Washington, DC, pp. 1-15.

Marashi-Pour, S., Cretikos, M., Lyons, C., Rose, N., Jalaludin, B., Smith, J., 2015. The association between the density of retail tobacco outlets, individual smoking status, neighbourhood socioeconomic status and school locations in new South Wales, Australia. Spat. Spatiotemporal. Epidemiol. 12:1-7. http://dx.doi.org/10.1016/j.sste.2014. 09.001.

Marquet, O., Miralles-Guasch, C., 2014. Walking short distances. The socioeconomic drivers for the use of proximity in everyday mobility in Barcelona. Transp. Res. A Policy Pract. 70:210-222. http://dx.doi.org/10.1016/j.tra.2014.10.007.

Mattioli, G., 2014. Where sustainable transport and social exclusion meet: households without cars and car dependence in great Britain. J. Environ. Policy Plan. 16: 379-400. http://dx.doi.org/10.1080/1523908X.2013.858592.

Miller, H.J., 2005. Place-based versus people-based accessibility. In: Levinson, D.M., Krizek, K.J. (Eds.), Access to Destinations. Elsevier, London, pp. 63-89.
Negron-Poblete, P., Séguin, A.-M., Apparicio, P., 2014. Improving walkability for seniors through accessibility to food stores: a study of three areas of Greater Montreal. J. Urban. Int. Res. Placemaking Urban Sustain. 9:51-72. http://dx.doi.org/10.1080/ 17549175.2014 .990916$.

Porta, S., Latora, V., Wang, F., Strano, E., Cardillo, A., Scellato, S., Iacoviello, V., Messora, R. 2009. Street centrality and densities of retail and services in Bologna, Italy. Environ. Plan. B Plan. Des. 36:450-465. http://dx.doi.org/10.1068/b34098.

Pueyo Campos, A., 2007. Zaragoza y la Expo 2008. Estud. Geol. LXVIII, 359-362.

Pueyo-Campos, A., Lopez-Escolano, C., Dieste Hernández, J., 2016. L'évolution de Saragosse vers la mobilité durable : le vélo comme mode de transport urbain. Consensus, paralysie et conflits d'un modèle en effervescence. Sud-Ouest Eur. 40, 101-114.

Roig-Tierno, N., Baviera-Puig, A., Buitrago-Vera, J., Mas-Verdu, F., 2013. The retail site location decision process using GIS and the analytical hierarchy process. Appl. Geogr. 40:191-198. http://dx.doi.org/10.1016/j.apgeog.2013.03.005.

Rotem-Mindali, O., 2012. Retail fragmentation vs. urban livability: applying ecologica methods in urban geography research. Appl. Geogr. 35:292-299. http://dx.doi.org/ 10.1016/j.apgeog.2012.08.003.

Saaty, R.W., 1987. The analytic hierarchy process - what it is and how it is used. Math. Model. 9:161-176. http://dx.doi.org/10.1016/0270-0255(87)90473-8.

Schwanen, T., Dieleman, F.M., Dijst, M., 2001. Travel behaviour in Dutch monocentric and policentric urban systems. J. Transp. Geogr. 9:173-186. http://dx.doi.org/10.1016 \$0966-6923(01)00009-6.

Scott, D., Horner, M., 2008. Examining the role of urban form in shaping people's accessibility to opportunities: an exploratory spatial data analysis. J. Transp. Land Use 1: 89-119. http://dx.doi.org/10.5198/jtlu.v1i2.25.

Soria-Lara, J.A., Valenzuela-Montes, L.M., 2014. Más allá de la estructura urbana y del patrón de viaje. El "entorno de movilidad" como instrumento para la planificación y la evaluación. Boletín la Asoc Geógrafos Españoles 64, 273-296.

Soria-Lara, JA., Valenzuela-Montes, L.M., Pinho, P., 2015. Using "mobility environments" in practice: lessons from a metropolitan transit corridor in Spain. J. Environ. Policy Plan. 17:553-572. http://dx.doi.org/10.1080/1523908X.2014.991779.

Soria-Lara, J.A., Aguilera-Benavente, F., Arranz-López, A., 2016. Integrating land use and transport practice through spatial metrics. Transp. Res. Part A Policy Pract. 91 330-345. http://dx.doi.org/10.1016/j.tra.2016.06.023.

Southworth, M., 2005. Designing the Walkable City. J. Urban Plan. Dev. 131:246-257. http://dx.doi.org/10.1061/(ASCE)0733-9488(2005)131:4(246).

Ståhle, A., Marcus, L., Karlström, A., 2005. Place Syntax - Geographic Accessibility with Axial Lines in GIS. Proc. 5th Int. Sp. Syntax Symp., pp. 131-144 (doi: 10.1.1.109.678)

Talavera, R., Soria-Lara, J.A., Valenzuela-Montes, L.M., 2014. La calidad peatonal como método para evaluar entornos de movilidad urbana. Doc. d'Analisi Geogr. 60 161-187.

Talavera-Garcia, R., Soria-Lara, J.a., 2015. Q-PLOS, developing an alternative walking index. A method based on urban design quality. Cities 45:7-17. http://dx.doi.org/ 10.1016/j.cities.2015.03.003.

te Brömmelstroet, M., 2015. A critical reflection on the experimental method for planning research: testing the added value of PSS in a controlled environment. Plan. Pract. Res. 30:179-201. http://dx.doi.org/10.1080/02697459.2015.1023077.

te Brömmelstroet, M., Bertolini, L., 2008. Developing land use and transport PSS: meaningful information through a dialogue between modelers and planners. Transp. Policy 15:251-259. http://dx.doi.org/10.1016/j.tranpol.2008.06.001.

Teller, C., Elms, J., 2010. Managing the attractiveness of evolved and created retail agglomerations formats. Mark. Intell. Plan. 28:25-45. http://dx.doi.org/10.1108/ 02634501011014598.

Teller, C., Reutterer, T., 2008. The evolving concept of retail attractiveness: what makes retail agglomerations attractive when customers shop at them? J. Retail. Consum. Serv. 15:127-143. http://dx.doi.org/10.1016/j.jretconser.2007.03.003.

Tight, M., Timms, P., Banister, D., Bowmaker, J., Copas, J., Day, A., Drinkwater, D., Givoni, M., Gühnemann, A., Lawler, M., Macmillen, J., Miles, A., Moore, N., Newton, R. Ngoduy, D., Ormerod, M., O'Sullivan, M., Watling, D., 2011. Visions for a walking and cycling focussed urban transport system. J. Transp. Geogr. 19:1580-1589. http://dx.doi.org/10.1016/j.jtrangeo.2011.03.011.

Vale, D.S Saraiva, M., Pereira, M., 2015. Active accessibility: a review of operational measures of walking and cycling accessibility. J. Transp. Land Use 1:1-27. http://dx.doi org/10.5198/jtlu.2015.593.

Van Acker, V., Witlox, F., 2010. Car ownership as a mediating variable in car travel behaviour research using a structural equation modelling approach to identify its dual relationship. J. Transp. Geogr. 18:65-74. http://dx.doi.org/10.1016/j.jtrangeo.2009.05. 006.

van Wee, B., 2011. Evaluating the impact of land use on travel behaviour: the environment versus accessibility. J. Transp. Geogr. 19:1530-1533. http://dx.doi.org/10 1016/j.jtrangeo.2011.05.011.

van Wee, B., 2016. Accessible accessibility research challenges. J. Transp. Geogr. 51:9-16 http://dx.doi.org/10.1016/j.jtrangeo.2015.10.018.

Wang, F., Chen, C., Xiu, C., Zhang, P., 2014. Location analysis of retail stores in Changchun, China: a street centrality perspective. Cities 41:54-63. http://dx.doi.org/10.1016/j. cities.2014.05.005.

Wang, Y., Chau, C.K., Ng, W.Y., Leung, T.M., 2016. A review on the effects of physical built environment attributes on enhancing walking and cycling activity levels within residential neighborhoods. Cities 50:1-15. http://dx.doi.org/10.1016/j.cities.2015.08. 004.

Wegener, M., Fuerst, F., 2004. Land-use transport interaction: state of the art. SSRN Electron. J. 1434678. http://dx.doi.org/10.2139/ssrn.1434678.

Willson, R., 2001. Assessing communicative rationality as a transportation planning paradigm. Transportation (Amst). 28, 1-31. 
Witlox, F., 2007. Evaluating the reliability of reported distance data in urban travel behaviour analysis. J. Transp. Geogr. 15:172-183

Wrigley, N., Dolega, L., 2011. Resilience, fragility, and adaptation: new evidence on the

performance of UK high streets during global economic crisis and its policy implica-tions. Environ. Plan. A 43:2337-2363.
Yazid, M.R.M., Ismail, R., Atic, R., 2011. The use of non-motorized for sustainable transportation in Malaysia. Protein Eng. 20:125-134.

Zandvliet, R., Bertolini, L., Dijst, M., 2008. Towards planning for a mobile society: mobile

and residential populations and the performance of places. Eur. Plan. Stud. 16. 